\title{
COVID-19: Paradox of increasing capacities versus focus on Hippocratic ethics?
}

\author{
George Anogeianakis* \\ Association for Training in Biomedical Technology, Thessaloniki, Greece
}

Received 9 April 2020, Accepted 10 April 2020

Keywords: COVID-19 pandemic, Healthcare system, Disease, Virus, Patient care

To the Editor,

The practice of Medicine must be patient centric, i.e., anthropocentric, which means that humankind is central. At least that is traditionally the duty of the physician who must use treatment to help the sick according to his/her ability and judgment [1]. The physician's efforts should be to cure patients - not merely to treat diseases. Finding cures for diseases is the role of the researcher - a job that seldom brings immediate and tangible results, especially at the height of a pandemic.

However, the present-day design of modern Health Care Systems is based on economic criteria, rather than on putting the patient at its core. This anthropocentric practice of medicine has been largely sidelined and thus the hospital has come to be equated with a factory and hospital efficiency concentrating on the factory production line where expediency and monetary gains usually dominate.

When unusual situations arise, such as the COVID-19 pandemic difficulties begin: the Health Care System becomes overloaded and is in danger of collapse under the weight of the rush of new cases over a short time frame. The production line fast reaches its limits and physicians can be confronted with the dilemma of who to save.

The immediate answer managers of factory-hospitals give is both simple and, at the same time, suitable for political exploitation: the need to have material and technical support to strengthening the infrastructure (i.e., the production line) with increasing capacities, ICU beds, materials and, incidentally, more staff.

However, the actual current pandemic data tell a different story!

On April 7, 2020, just before midnight, the number of COVID-19 infections within the European Union (EU) exceeded 650,000 with a death toll of 54,500.

A simple statistical review of the results of the increased availability of ICU beds in the EU shows that irrespective of whether a country has a lot of ICU beds or just a few, the

*Corresponding author: anogian@auth.gr death rates due to COVID-19 is still the same $(P=0.34$, Fig. 1 and Tab. 1).

The question that, therefore arises is: How does the paradox of non-correlation between the number of ICU beds and the number of deaths arise? Is this paradox the result of poor system design, whereby the government's (narrow) view of what healthcare economics must achieve, prevails over the Hippocratic duty that the physicianoperators of the system are bound by oath and indenture [1] adhere to?

An answer to the paradox comes from a group of intensive care physicians from long-suffering Italy [2], who claim that, at present, attention is focused mainly on increasing capacities (e.g., the number of ICU beds, respirators and intensive care units, etc.). At the same time, they claim, that the clinical approach to COVID-19 patients is based on the Berlin guidelines for treating the Acute Respiratory Difficulty Syndrome (ARDS). However, patients with COVID-19 pneumonia, despite the fact that they meet the ARDS (Berlin) criteria, present with a non-typical form of ARDS. The same team of intensive care physicians

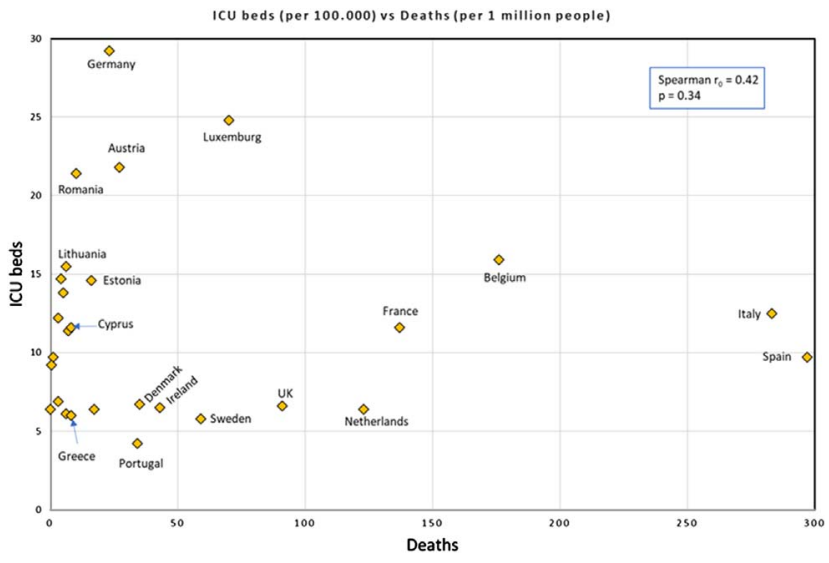

Figure 1. A statistical review of ICU beds (per 100,000) versus deaths (per 1 million people) in European Union. 
Table 1. COVID-19 deaths $/ 1,000,000$ population and ICU beds/100,000 population in the EU countries.

\begin{tabular}{|c|c|c|}
\hline Country & $\begin{array}{l}\text { COVID-19 deaths/ } \\
1,000,000 \text { population }\end{array}$ & $\begin{array}{c}\text { ICU beds/ } \\
100,000 \text { population }\end{array}$ \\
\hline Austria & 27 & 21.8 \\
\hline Belgium & 176 & 15.9 \\
\hline Bulgaria & 3 & 12.2 \\
\hline Croatia & 4 & 14.7 \\
\hline Cyprus & 7 & 11.4 \\
\hline Czechia & 8 & 11.6 \\
\hline Denmark & 35 & 6.7 \\
\hline Estonia & 16 & 14.6 \\
\hline Finland & 6 & 6.1 \\
\hline France & 137 & 11.6 \\
\hline Germany & 23 & 29.2 \\
\hline Greece & 8 & 6 \\
\hline Hungary & 5 & 13.8 \\
\hline Ireland & 43 & 6.5 \\
\hline Italy & 283 & 12.5 \\
\hline Latvia & 1 & 9.7 \\
\hline Lithuania & 6 & 15.5 \\
\hline Luxembourg & 70 & 24.8 \\
\hline Malta & 0 & 6.4 \\
\hline Netherlands & 123 & 6.4 \\
\hline Poland & 3 & 6.9 \\
\hline Portugal & 34 & 4.2 \\
\hline Romania & 10 & 21.4 \\
\hline Slovakia & 0.4 & 9.2 \\
\hline Slovenia & 17 & 6.4 \\
\hline Spain & 297 & 9.7 \\
\hline Sweden & 59 & 5.8 \\
\hline UK & 91 & 6.6 \\
\hline
\end{tabular}

conclude [3] that a good understanding of pathophysiology is vital to choosing the right treatment for any given COVID-19 patient.
In other words, they imply that one should avoid the irrational use of treatment protocols and return to the anthropocentric medical practice, where the patient is the focus of treatment and not the disease. Then and only then: the increase of capacities will be justified in the fight against COVID-19, with the consequence, that we will be able to measure how many ICU beds we really need, and physicians will not be faced with the dilemma of who to save.

\section{Conflict of interest}

The author, George Anogeianakis, certifies that he has no financial conflict of interest (e.g., consultancies, stock ownership, equity interest, patent/licensing arrangements, etc.) in connection with this article.

\section{References}

1. LOEB Classical Library (2020), Hippocrates of Cos, The Oath, Harvard University Press. https://www.loebclassics.com/ view/hippocrates_cos-oath/1923/pb_LCL147.299.xml; jsessionid =1D5671FB44BBD0D2088B 753 FC53D9AFB

2. Gattinoni L, Coppola S, Cressoni M, Busana M, Rossi S, Chiumello D (2020), Covid-19 does not lead to a "Typical" Acute Respiratory Distress Syndrome. Am J Respir Crit Care Med [Online ahead of print]. https://doi.org/10.1164/ rccm.202003-0817LE; PubMed: 32228035.

3. Gattinoni L, Chiumello D, Caironi P, Busana M, Romitti F, Brazzi L, Camporota L (2020), Editorial: COVID-19 pneumonia: Different respiratory treatment for different phenotypes. Intensive Care Med; https://doi.org/10.1007/s00134020-06033-2. 